\title{
PENINGKATAN HASIL BELAJAR TEMATIK TERPADU MENGGUNAKAN MODELCOOPERATIVELEARNING TIPE CRH DI SD
}

\author{
Surtika Sari ${ }^{1}$, Mai Sri Lena ${ }^{2}$ \\ 1,2Universitas Negeri Padang \\ 1surtikasari30@gmail.com , maisrilena@fip.unp.ac.id
}

\begin{abstract}
This study aims to determine the improvement of integrated thematic learning outcomes using the $\mathrm{CRH}$ Cooperative Learning model. This research is a classroom action research that uses qualitative and quantitative approaches. The subjects used in this study consisted of teachers and 32 students. This research was conducted 2 cycles. Cycle I was held for 2 meetings and cycle II was held for 1 meeting, with four stages, namely planning, implementation, observation and reflection. The results of this study are : the percentage observations of RPP in the first cycle, $78 \%$ increased in the second cycle, $95 \%$. The result of observation of teacher aspect in cycle 1,78,75\% increased in cycle $11,92,5 \%$. The results of the observations of students in the first cycle, $81.25 \%$ increased in the second cycle, 92.5\%. Student learning outcomes in the first cycle, 67,18\% (C) increased in the second cycle $92,4 \%$ (SB).
\end{abstract}

Keyword: Course Review Horay, Learning Outcomes, Integrated Thematic

\begin{abstract}
ABSTRAK
Penelitian ini bertujuan untuk mengetahui peningkatan hasil belajar tematik terpadu dengan menggunakan model Cooperative Learning tipe $\mathrm{CRH}$. Penelitian ini adalah penelitian tindakan kelas yang menggunakan pendekatan kualitatif dan kuantitatif. Subjek yang digunakan pada penelitian ini terdiri dari guru dan 32 orang peserta didik. Penelitian ini dilakukan dalam 2 siklus. Siklus I dilaksanakan sebanyak 2x pertemuan dan siklus II dilaksanakan sebanyak 1x pertemuan, dengan adanya empat tahapan yaitu perencanaan, pelaksanaan, pengamatan dan refleksi. Hasil penelitian ini yaitu :persentase pengamatan RPP siklus I, 78\% meningkat pada siklus II, 95\%. Hasil pengamatan aspek guru siklus I,78,75\%meningkat pada siklus II, 92,5\%. Hasil pengamatan peserta didik siklus I, $81,25 \%$ meningkat pada sikus II, 92,5\%. Hasil belajar peserta didik pada siklus I, $67,18 \%$ (C) meningkat pada siklus II 92,4\% (SB).
\end{abstract}

Kata kunci : Course Review Horay (CRH), Hasil Belajar, Tematik Terpadu

\section{A. Pendahuluan}

Pembelajaran pada program

kurikulum 2013 menggunakan pembelajaran tematik dari kelas I-IV. Kurikulum 2013 menerapkan kegiatan pembelajaran secara keseluruhan, 
dimana

aktivitas

belajar

mengikutsertakan pasrtisipasi siswa dengan aktif sehingga aktivitas belajar mengajar terfokus untuk siswa (Kurniasih, 2014). Pembelajaran tematik membutuhkan partisipasi siswa yang lebih aktif didalam kegiatan pengajaran, hasilnya kemampuan siswa untuk lebih terlatih secara langsung dengan lebih cakap agar mendapati dengan sendirinyawawasan yang lebih luas dalam pembelajarannya (Prastowo, 2013).

Apabila perencanaan dan pelaksanaan pembelajaran tematik telah dilaksanakan dengan baik, sehingga akan mempengaruhi hasil belajar siswa. Pengajaran tematik bertujuan untui meningkatkan hasil belajar siswa yang optimal dengan melakukan proses pengajaran yang benar (Kadir dan Asrohah, 2014).

Hasi belajar peserta didik secara umum dapat merubah perilaku seperti sikap, pengetahuan, dan keterampilan. Hasil belajar dapat dilihat dengan melakukan evaluasi pada peserta didik. Untuk mencapai hasil belajar yakni dengan melakukan evaluasi, baik evaluasi yang menjadi langkah berikutnya maupun pengukuran tingkat penguasaan peserta didik terhadap pembelajaran (Jihad dan Aris, 2013).

Sesuai hasil dari wawancara serta hasil mengamati, ketika penerapan observasi dikelas IV SDN 21 Batang Anai Kab.Padang Pariaman tanggal 13 Oktober 2020 pada Subtema 3 "Ayo Cintai Lingkungan" dan tepatnya pada tema 3 yakni "Peduli Terhadap Makhluk Hidup", Pembelajaran 3 dengan mata pelajaran Bahasa Indonesia, PJOK, dan IPA, kemudian ditanggal 15 Oktober 2020 pada tema dan subtema yang sama pembelajaran 3 dengan mata pelajaran Bahasa Indonesia, PJOK dan IPA dan ditanggal 19 Oktober 2020 pada tema dan subtema yang sama pembelajaran 5 dengan mata pelajaran PJOK, PPKn dan Bahasa Indonesia.

Permasalahan yang peneliti temui saat observasi dikelas IV SDN 21 Batang Anai Kab. Padang Pariaman pada tanggal 13, 15 dan 19 Oktober 2020, terdapat berbagai permasalaahan yang dialami guru dan peserta didik, yatu pada perencanaan pembelajaran, guru belum mengembangakan pembuatan rencana pelaksanaan pembelajaran (RPP). Hal ini terlihat dalam RPP yang digunakan yaitu hanya berpedoman 
pada buku guru yang belum dianalisis kesesuaian antar komponen yang terkandug dalam perangkat pembelajaran.

Pelaksanaan kegiatan belajar mngajar yang dipergunakan oleh guru yang mendominasi dalam proses pemebelajaran tetap kepada yang berpusat pada guru, mata pelajaran yang diajarkan masih terpisah-pisah, guru belum memberikan stimulus atau rangsangan saat proses pembelajaran dengan permasalahan nyata yang dekat dengan lingkungan siswa, serta kurangnya guru dalam membimbing siswa didalam menyimpulkan materi diakhir pembelajaran.

Masalah ini berdampak pada siswa, yakni: 1) banyak siswa yang lebih mendengarkan penejelasan guru, 2) siswa tidak termotivasi agar melakukan pembelajaran yang aktif, 3) siswa lebih sedikit mendapatkan pengalaman langsung didalam kegiatan belajar mengajar, 4) siswa sering lupa dengan pengajaran yang sudah dipelajari dikarenakan kurangnya bimbingan guru diakhir pembelajaran.

Pengajaran yang dilakukan sebagaimana yang diuraikan tersebut, juga berdampak pada hasil belajar siswa. Untuk siswa yang hasil belajarnya belum mencapai apa yang targetnya, tetap saja kebanyakan siswa yang belum mencapai ketuntasan minimal belajar (KBM).

Berdasarkan permasalahan yang peneliti temukan, salah satunyasebagai pengupayaan agar menyelesaikan masalah tersebut yakni dengan penerapan model pemebelajaran yang inovatif serta kreatif. Maka penulis menemukan solusi dengan menerapakan model Cooporative Learningtipe Course Review Horay $(\mathrm{CRH})$ dikelas IV SDN 21 Batang Anai Kab. Padang Pariaman. Tipe $\mathrm{CRH}$ merupakan salah satu tipe Cooperative learning yang bisa membikin keadaan dikelas dengan menggembirakan serta meriah bagi peserta didik, perlakuannya yakni menguji pemahaman peserta didik tentang jawaban atas pertanyaan terkait materi yang dikemas dalam kelompok kecil setelah itu menuliskan pertanyaan di kertas yang sudah diberi nomor lalu dimasukkan ke dalam kotak dan masing-masing siswa yang memberi jawaban dengan tepat diwajibakan meneriakkan beberapa yel yang disukainya ataupun dengan kata-kata "hore". 
Pada proses pembelajaran model CRHini dilaksanakan dengan beberapa langkah yaitu : (a)Penyampaian Guru tentang kompetensi yang hendak di targetkan. (b) Guru menerangkan atau memperagakan konsep menurut poin tanya jawab. (c) Guru membentuk 5-6 kelompok. (d) Siswa dimintakanagar membikin kotak ataupun kartu yang menyesuaikan pada kebutuhanan,kemudian kotak ataupun kartu itu pengisiannya berdasarkan penomoran yang ditetapkan olehpengajar. (e) Guru menyebutkan pertanyaan dengan mengacak serta siswa menuliskannyatanggapan pada kartu atau kotak dengan nomor yang disampaikan oleh guru. (f) Sesudah membacakan pertanyaan serta memberi tanggapan peserta didik, siswa dan guru melakukan diskusi pertanyaan sebelumnya. (g) Untuk soal dengan jawaban yang tepat, siswa membuat cheklist $(\sqrt{ })$ serta dengan spontan meneriakkan kata "hore!!" atau bernyanyi dengan yel-yel yang sudah dipersiapkan. (h)Untuk nilainyabagi peserta didik dengan cara dari soal yang dijawab dengan tepat dan yang meneriakkan kata "hore!!", (i) Guru memberi penghargaan kepada kelompok dengan skor paling tinggi dan kelompok yang kerapmendapatkan "hore!!”

Tipe pembelajaran kooperatif $(\mathrm{CRH})$ dipilih karena memiliki beberapa keunggulan yaitu : 1) pembelajaran yang atraktifdan dapat menggerakkan siswa yang ada dalam prosesnya, 2) tidak monoton dikarenakansecara bergantian cukup menghibur agar kondisi tidak membuat tegang, 3) siswa lebih antusias, 4) memberi latihan untuk dapat bekerja sama (Shoimin, 2014).

Sesuai penjelasan yang sudah diuraikan, peneliti memiliki ketertarikan agar meneliti berupa tindakan kelas yang judulnya "Peningkatan Hasil Belajar Peseta Didik Pada Pembelajaran Tematik Terpadu Menggunakan Model Cooperative Learning Tipe Course Review Horay(CRH) Di Kelas IV SDN 21 Batang Anai Kab. Padang Pariaman"

\section{B. Metode Penelitian}

\section{Waktu dan Tempat Penelitian}

Kajian ini penerapannya pada SDN 21 Batang Anai. Peneliti melaksanakan penelitian di SD ini dengan beberapa pertimbangan yaitu : (a)Guru bersedia melibatkan peneliti 
dalam penelitian agar membuat peningkatan hasil belajar siswa, (b) sekolah ini telah memakai kurikulum K13, (c) Sekolah bersedia dan mengapresiasi penelitian yang dilakukan di SDN 21 Batang Anai, (d) penggunaan model Course Review Horay masih jarang digunakan dalam pembelajaran di SDN 21 Batang Anai.

\section{Subjek Penelitian}

Didalam kajian ini untuk subjeknyaadalah siswa dan guru dikelas IV SDN 21 Batang Anai Kab.Padang Pariaman dengantotal 32 peserta didik yang termasuk dari 20 siswa priaserta 12 orang wanita yang sesuai daftar siswa disemester II Kota Padang tahun pembelajaran 2020/2021. Sedangkan yang berpartisipasididalam kajian iniialah penulis yang menjadi observer dan guru kelas sebagai praktisi.

\section{Waktu dan Lama Penelitian}

Kajian ini untuk penerapannya disemester II Tahun pembelajaran 2020/2021. Penelitian ini penerapannya sebanyak 2 siklus, yakni untuk pertemuannya dengan masing-masing siklus 1 dan 2 yakni dilakukan 2 kali serta 1 kali tatap muka.

\section{Pendekatan Penelitian}

Penelitian ini berfokus pada merencanakan, keterlaksanaan, dan penilaian hasil belajar dengan mempergunakan metode kuantitatif serta kualitatif. Metode kualitatif ialah metode dengan data yang dihasilkan yakni data deskriptif yang disajikan sebagai kata-kata yang ditulis secara alamiah dan tidak dimanipulasi oleh keadaan atau kondisi.Metode kualitatif dipergunakan dengan alasan data atau informasinya dapat membentuk kalimat informasi yang berhubungan pada aktivitas mata pelajaran yang dipahami oleh siswa (Kunandar, 2011).

$\begin{array}{llr}\text { Metode } & \text { kuantitatif } & \text { sebagai } \\ \text { parameter } & \text { hasil kajian } & \text { yang } \\ \text { diterapkan dengan kajian } & \text { ilmiah }\end{array}$
menurut aturan sesuai kata yang tersaji didalam penelitiansebagai bentuk berupa analisa statistik serta dalam bentuk angka. Metode kuantitatif merupakan proses menemukan pengetahuan dengan hasilanalisis data dalambentuk statistik (Lena, 2019).

\section{Jenis Penelitian}

Jenis kajian yang peneliti gunakan yaitu Penelitian Tindakan Kelas (PTK). PTKmempunyai peran yang begitu pokok serta penting dalam peningkatan kualitas pengajaran bila dilakukan secara tepat 
dan akurat.

PTK ini ialah dengan perlakuan dari pendidik semacam refleksi diri ketika memecahkan masalah didalam kegiatan belajar mengajar dikelas dan dapat memperbaiki situasi pembelajar dan kemudian mengukur tingkat keberhasilan. PTK ialah jenis kajian yang menggambarkan hasil proses dan kegiatan untuk peningkatan kualitas pengajaran di kelas (Arikunto, 2015).

\section{Alur Penelitian}

Kajian ini diterapkan dengan perlakuan model siklus-siklus, dengan pengembangan berdasarkan pendapat Kemmis, yakni merencanakan, keterlaksanaan, mengamati serta merefleksi merupakan empat komponen yang berdasar pada siklus (Arikunto, 2015). Penelitian tindakan kelas dilaksanakan dalam 2 siklus, yakni untuk pertemuannya dengan masingmasing siklus 1 dan 2 yakni dilakukan 2 kali serta 1 kali tatap muka.

\section{Prosedur Penelitian}

Kegiatan pelaksanaan penelitian ini mencakup tahaptahapmerencanakan, keterlaksanaan, mengamati/observasi serta merefleksi. Pada tahapanmerencanakan, dapat dijelaskan yakni: a) penentuan penjadwalanproses pengkajian, menganalisa kurikulum 2013, buku yang dipakai oleh siswa atau buku siswa maupun buku yang dipakai oleh guru atau buku guru, c) penyusunan perencanaan pembelajaran (RPP) sesuai langkah pembelajaran model $\mathrm{CRH}$, tatap muka ke 1 pada siklus I dengan tema 8sesuai ketentuan yakni tema (Daerah Tempat Tinggalku) dengan subtemanyake 1 sesuai urutan yakni (Lingkungan Tempat Tinggalku) pembelajaran 1, tatap muka ke 2 pada siklus I dengan tema 8 sesuai ketentuan yakni tema (Daerah Tempat Tinggalku) dengan subtemanyake 2pembelajaran 1 dan disiklus II dengan tema yang sama dan subtemanyake 3sesuai urutan yakni (Bangga Terhadap Daerah Tempat Tinggalku) pembelajaran 1. Yang terdiri dari: Identitas, Kompetensi Inti, Kompetensi Dasar, Indikator, penentuan target pengajaran, pemilihan serta penetapan materi ajar, penentuan model, menyusun kegiatan belajar mengajar, pemilihan media, sumber belajar, lembar kerja peserta didik, evaluasi dan penilaian, d) menyediakan perangkat untuk mengumpulkan data atau informasi misalnya saja hasil evaluasi RPP, lembar non tes serta lembar tes, e) berdiskusi bersama guru 
kelas berkaitan metode untuk mengumpulkan dataatau informasi dengan melakukan pengamatan ketika penerapan dalam aktivitas, sehingga tidak ada kesalahan saat proses mengambil data atau informasi.

Tahapan keterlaksanaan dapat digambarkan sebagai berikut: a) peneliti sebagai praktisi melakukan pembelajaran dengan model $\mathrm{CRH}$ yang menyesuaikan RPP yang dirancang. b) sebagai observer guru kelas mengamati sesuai sistematika lembar observasi baik pada aktivitas guru maupun peserta didik dalam proses pembelajaran, c) penulis serta guru mendiskusikan perlakuan yang telah diterapkan, selanjutnya merefleksi sebagai proses menyempurnakan berikutnya.

Tahapan pengamatan untuk melakukan perlakuan pembelajaran tematik dikelas IV SDN 21 Batang Anai Kab. Padang Pariaman dengan mempergunakan model $\mathrm{CRH}$ dengan perlakuan yang sistematis, objektif dan intensif. Observasi oleh guru sebagai observer beriringan dengan pelaksanaan tindakan pembelajaran yang dilakukan peneliti. Pengamatan akan dijalani oleh guru sebagai observer saat waktu peneliti melakukan kegiatan pembelajaran tematik.

Selama tahap refleksi peneliti dan guru membahas tindakan yang baru saja dilakukan. Hasilrefleksi dapat dijadikan masukan untuk tindakan yang akan dilakukan selanjutnya, serta pada masingmasing perlakuan bermanfaat sebagai penyusunan kesimpulan hasil penerapan disiklus I serta siklus II.

\section{Data Penelitian}

Data penelitian ialah hasil observasi berdasarkan setiap tindakan didalam pengajaran tematik dengan mempergunakan model $\mathrm{CRH}$ dikelas IV SDN 21 Batang Anai Kab. Padang Pariaman.

Data ini terkait dengan merencanakan, keterlaksanaan serta hasil pembelajaran yaitu : a) RPP berkaitan dengan kesiapan guru sebelum pengajaran dengan menggunakan model $\mathrm{CRH}$ agar terjadi peningkatan hasil pembelajaran dikelas IV, b) dengan menerapkan model $\mathrm{CRH}$ keterlaksanaan pengajaran tematik berkaitan dengan aspekguru serta aspek siswa, dimulai darikegiatan diawal, kegiatan pokok serta kegiatan penutupanpengajaran, c) hasil pembelajaran tematik dengan memakai model $\mathrm{CRH}$ terkait dengan aspek-aspek sikap, pengetahuan 
serta praktik.

\section{Sumber Data}

Sumber informasi atau data didalam kajian ini ialah proses pengajaran dengan mempergunakan model CRH dikelas IV SDN 21 Batang Anai Kab.Padang Pariaman, yang mencakup merencanakan pengajaran, keterlaksanaan pengajaran yang meliputi dari aktivitas awal, pokok serta penutup, serta aspek guru dan aspek peserta didik untuk proses pengajaran. Data dikumpulkan berdasarkan subjek penelitian, yakni siswa dan guru dikelas IV SDN 21 Batang Anai Kab. Padang Pariaman.

\section{Data Penelitian}

Data atau informasi untuk kajian ini untuk mengumpulkannya dengan penggunaan hasil tes serta pengamatan. Uraian setiap data sesuai penjelasan berikut: a) dokumen analisis, penilaian rpp yaitu mennetukan apakah baik atau tidaknya suatu rpp yang dibuat untuk diterapkan saat pembelajaran, b) penerapan pengamatan sebagai proses obeservasi proses pengajaran yang terjadi berdasarkan lembar pengamatan yang ditentukan, c) pengujian tes sebagai proses mendapatkan data atau informasi yang tepat tentang pemahaman peserta

didik

didalam menangkappengajaran tematik, d) lembar non tes dipergunakan agar mengetahui hasil pembelajaransiswa ditinjau berdasarkan sikap serta kemampuan.

\section{Instrumen Penelitian}

Yang dipergunakan pada kajian ini yaitu lembaranevaluasi rpp, lembaranpengamatan dan lembaran non tes serta lembaran tes.

\section{Analisis Data}

Data atau informasi yang didapatkan dilakukan analisa dengan memakai data kuantitatif serta kualitatif. Analisis data kualitatif bersifat induktif, khususnya analisis berdasarkan data yang didapatkan dan analisa data kuantitatif merupakan data yang disajikan dengan bentuk bilangan (Sugiyono, 2015).

C. Hasil Penelitian dan

\section{Pembahasan}

\section{Hasil Penelitian Siklus I}

a. Perencanaan Siklus I

Perencanaan

pengajaran dinyatakan didalam bentuk rancangan pengajaran atau rpp. Penyusunan rpp didasarkan pada kurikulum 2013. Sebelum rpp dibuat, peneliti terlebih dahulu pembelajaran 
yang akan dibelajarkan dan dikembangkan dengan menggunakan model CRH dikelas IV SDN 21 Batang Anai Kab. Padang Pariaman.

Tema yang digunakan disiklus I pertemuan 1 yaitu tema 8 subtema 1 , pembelajaran 1, pelajaran yang harus dipelajari yang terpaut ialah IPA serta Bahsa Indonesia. Proses merencanakan disiapkan dengan satu kali pengajaran, dibagi menjadi satu kali pertemuan yaitu $5 \times 35$ menit pada tanggal 24 Februari 2021. Setelah itu peneliti menetapkan KI, KD serta membuat indikator dari kemampuan yang akan dicapai oleh peserta didik.

Perencanaan tindakan pada siklus I pertemuan 2 hampir sama dengan penyusunan perencanaan dengan pertemuan sebelumnya. Kemudian penyusunan rpp, penulis menganalisamasing-masing kompetensi dasar yang dapat dilakukan pengembangan didalam buku siswa ataupun buku guru kurikulum 2013 dikelas IV tema 8 semester 2. Rpp ini disusun berdasarkan waktu penelitian dengan durasi $5 \times 35$ menit atau 1 hari pembelajaran dan waktunya pada hari Rabu , 03 Maret 2021.
Materi pembelajaran yang digunakan yaitu dari buku siswa, buku guru, buku tambahan yang sesuai serta internet.Dengan menyesuaikan pada tema 8 "Daerah Tempat Tinggalku" dengan subtemanyake 2 "Keunikan Daerah Tempat Tinggalku" pembelajaran 1 , memiliki $\mathrm{KI}, \mathrm{KD}$, indikator, target pengajaran, materi pengajaran, kegiatan pembelajaran, sumber pembelajaran serta media, metode dan model pengajaran, serta evaluasi.

\section{Pelaksanaan Siklus I}

Proses penelitian yang dilaksanakan dengan mempergunakan model $\mathrm{CRH}$ dikelas IV SDN 21 Batang Anai Kab. Padang Pariaman pada siklus I pertemuan1 dilakukan pada tanggal 24 Februari 2021 hari Rabu. Pembelajaran berlangsung selama $5 \times 35$ menit. Tema yang dipakai disiklus I ini yaitu tema 8 (Daerah Tempat Tinggalku), dengan subtemanya ke 1 (Lingkungan Tempat Tinggalku), pembelajaran 1. Dengan materi ajar yang terpaut pada pembelajaran 1 yaitu IPA serta Bahasa Indonesia. Pelaksanann pembelajaran menyesuaikan pada tahapan-tahapan model $\mathrm{CRH}$.

Aktivitas pengajaran tematik yang menggunakan model $\mathrm{CRH}$ dikelas IV 
SDN 21 Batang Anai Kab.Padang

Pariaman. Siklus I pertemuan 2 dilakukan pada hari Rabu, 03 Maret 2021. Waktu pembelajaran sama dengan pertemuan sebelumnya. Dengan tema pengajaran disiklus I ialah 8 , subtema 2, pembelajaran 1. Materi yang terkait yaitu Bahasa Indonesia dan IPA. Pelaksanaan pembelajaran sesuai dengan langkahlangkah model $\mathrm{CRH}$.

\section{Pengamatan Siklus I}

Pengamatan Aspek Penilain RPP Siklus I

Observasi yang dilaksanakan terhadap penelitian dilembar rpp pada siklus I tatap muka 1 menghasilkan nilai 29 dengan nilai maksimum 40, jadi skoruntuk siklus I tatap muka ke 1 ialah $72,5 \%$ dan termasuk dalam kategori cukup (C).

Observasi

yang

dilaksanakanpada lembar penilaian rpp siklus 1 tatap muka ke 2 yaitu 34 dengan skor maksimal 40, maka nilai siklus 1 pertemuan 2 adalah $85 \%$ dan termasuk dalam kategori baik (B).

Jadi hasill observasiperoleh dilembar observasi rpp yaitu dengan reratanya $79 \%$ dan termasuk dalam kategori cukup (C).

Pengamatan Aspek Guru Siklus I
Berdasarkan observasi dari kegiatan yang dilaksanakan disiklus I tatap muka ke 1 diperoleh nilai sebanyak 30 dengan nilai maksimum 40. Jadi persentase nilai aktivitas guru adalah $75 \%$. Halini memperlihatkan bahwasannyastnadar berhasilnya gurudidalam melakukan pengajaran tematik tercakup dengan kategori cukup (C).

$\begin{array}{ccr}\text { Pada } & \text { pertemuan } & 2 \\ \text { dihasilkandari } & \text { pegamatan yang }\end{array}$ dilakukan oleh guru mendapatkan skor yaitu 35 dengan skor maksimal 40. Oleh karena itu persentase skor kegiatan guru ini ialah $87,5 \%$. Yang memperlihatkan

bahwasannyadindikator berhasilnya guru didalam melakukan pengajaran tematik tercakup dengan kategori baik (B).

Dengan demikian, yang dihasilkan dari observasi akan kegiatan yang dilaksanakan peneliti selama pengajaran disiklus I, persentase nilai yang diperoleh 81,25\%. Yang memperlihatkan bahwasannyaindikator berhasilnya guru ketika melakukan pengajaran tematik tercakup dengan kategori baik (B).

Pengamatan Aspek Peserta Didik Siklus I 
Pada observasi yang sudah dilaksanakan oleh observer atas kegiatan siswa disiklus I tatap muka ke 1 dengan nilai 30 dan skor maksimal 40. Persentase nilai peserta didik yaitu $75 \%$. Halini menunjukkan bahwa keberhasilan peserta didik ketika melakukan proses belajar tematik tercakup dengan kategori cukup (C).

Sesuai observasi yang dilaksanakan untuk kegiatan peserta didik pada kegiatan pembelajaran kedua, mendapatkan skor maksimal 35 dari jumlah skor maksimal 40. Persentase nilai aktivitas peserta didik sebesar $87,5 \%$. Halini memperlihatkan indikator berhasilnya peserta didik saat pelaksanaan pengajaran tematik tercakup dengan kategori baik (B).

Jadi hasil observasi yang dilaksanakan atas kegiatan siswa saat kegiatan pengajaran disiklus I ini memperoleh nilai yang rataratanya $\quad 81,25 \%$. Yang memperlihatkan bahwasannya standar berhasilnya peserta didik saat melakukan proses belajar tematik tercakup kedalam kategori baik (B).

Pengamatan Hasil Belajar Siklus I
Evaluasi

hasil pembelajaransiswa saat melakukan proses belajar tematik dengan penerapan model pemebelajaran $\mathrm{CRH}$ untuk disiklus I tatap muka ke 1 didapatkan skor ketuntasan yakni $56,25 \%$. Siswa yang mendapatkan nilai sesuai standar 18 orang. Disiklus I tatap muka ke 2 memperoleh nilai ketuntasan $78,12 \%$, dengan total siswa yang memperoleh nilai ketuntasan yaitu 25 siswa.

Dengan demikian , dari pengamatan yang sudah dilaksanakan disiklus I persentase yang didapatkan yakni $67,18 \%$.

\section{Refleksi Siklus I}

Refleksi disiklus I untuk kesimpulan bahwasannyasasaran pengajaran yang menjadi target disiklus ini belum sesuai yang diharapkan. Sehingga usaha agar meningkatkan pelaksanaan pengajaran tematik menggunakan model $\mathrm{CRH}$ peneliti melanjutkan pada siklus II dan peneliti memperhatikan beberapa kelemahan yang terdapat disiklus I. Kekurangan tersebut dapat dilakukan perbaikan disiklus II.

\section{Hasil Penelitian Siklus II}

\section{Perencanaan Siklus II}

Hasil yang diperoleh dari analisis siklus menunjukkan 
bahwasannyasasaran

yang

dimaksudkan pada penelitian belum berhasil, hali ini disebabkan kurangnya sistem dalam implementasi perancangan yang sudah dibentuk. Sehingga pembelajarann untuk berikutnya lanjut ke siklus II.

Pembuatan

rencana pengajaran disiklus II tidak begitu terdapat perbedaan yang ada pada perancangan pengajaran disiklus sebelumnya. RPP masih direncanakan berdasarkan tema delapan (Daerah Tempat Tinggalku) dengan subtemanyake tiga (Bangga Terhadap Tempat Tinggalku). Pengajaran satu dengan penerapan model $\mathrm{CRH}$. RPP ini disusunsesuai ketersediaan waktu yakni satu kali tatap muka dengan 5x35 menit atau 1 hari pembelajaran pada 24 Februari 2021.

\section{Pelaksanaan siklus II}

Keterlaksanaan pengajaran disiklus II tema delapan (Daerah Tempat Tinggalku) pembelajaran 1 dilakukan di hari Rabu tanggal 10 Maret 2021. Didalam keterlaksanaan perlakuan yang diterapkan, pengkaji menjadi pengamat serta guru kelas IV menjadi praktisi. Langkah-langkah dalam pelaksanaan kegiatan pembelajaran disesuaikan dengan model $\mathrm{CRH}$.

\section{Penggamatan Siklus II}

\section{Pengamatan Aspek RPP Siklus II}

Sesuai observasi pada lembar evaluasi RPP yang dilaksanakan oleh pengamat disiklus II mendapatkan skor 38 sesuai nilai maksimum 40, jadi persentase nilai yang didapatkan ialah 95\% yang tercakup dengan kategori sangat baik (SB).

\section{Pengamatan Aspek Guru Siklus II}

Hasil pengamatan yang dilakukan pada aspek guru dengan hasil pengamatan disiklus II ini mendapatkan skor 37 berdasarkan jumlah skor maksimum 40. Maka persentase nilai untuk aktivitas guru adalah 92,5\%. Kriteria guru dalam keberhasilan melaksanakan kegiatan belajar menunjukkan pada kategori sangat baik (SB).

\section{Pengamatan Aspek Peserta didik} Siklus II

Dalam kegiatan penhajaran disiklus II, pengamat melaksanakan observasi terhadap aktivitas peserta didik dengan memperoleh skor 37 serta nilai maksimum 40. Sehingga persentase skor aktivitas peserta didik yaitu $92,5 \%$. Yang mana memperlihatkan bahwasannyaindikator berhasilnya 
peserta didik melakukan proses belajar tematik sudah sangat baik.

\section{Pengamatan Hasil Belajar Siklus II}

Disiklus II penilaian yang diperoleh siswa didalam aktivitas belajar mengajar tematik yang memakai model $\mathrm{CRH}$ memperoleh nilai ketuntasan 92,54\%, total siswa dengan nilai ketuntasan yaitu 31.

\section{Refleksi Siklus II}

Sesuai hasil pengamatan disiklus II diketahui bahwasannya perencanaan, pelaksanaan, dan hasil pembelajaran diketahui bahwa pembelajaran tematik terjadi peningkatan serta telah relevan atas apa yang menjadi harapan. Dari hal tersebut

kesimpulannya bahwasannyakajian disiklus II sudah sesuai indikator yang diinginkan. Oleh karena itu kajian berakhir disiklus II serta tidak lanjut disiklus selanjutnya.

Sedangkan yang termasuk pada bahasan dalam kajian ini ialah bagaimana RPP tematik yang memakai model $\mathrm{CRH}$, bagaimana proses pengajaran tematik yang memakai model $\mathrm{CRH}, \quad$ bagaimana hasil pembelajaransiswa dengan model $\mathrm{CRH}$.

Sesuai hasil refleksi disiklus I serta siklus II bisa diketahui bahwasannya hasil pembelajaran tematik dengan mempergunakan model $\mathrm{CRH}$ dikelas IV SDN 21 Batang Anai Kab. Padang
Pariaman tahun ajaran 2021/2022 telah meningkat. Hasil belajar dapat meningkat karena langkah-langkah pembelajaranmemakai model Coperative Learning tipe Course Riview Horay $(\mathrm{CRH})$ sudah terlaksana dengan baik serta tujuan pembelajaran yang diharapkan sudah tercapai.

\section{Kesimpulan}

Sesuai hasil kajian serta penjelasan maka untuk kesimpulan bahwasannya penilaian pengamatan RPP disiklus I diperoleh nilai $79 \%$ dan termasuk kategori baik. Disiklus II terjadi peningkatan yakni $95 \%$ yang termasuk kriteria sangat baik.Berdasarkan hasil observasi dapat dilihat bahwa perencanaan pengajaran tematik dengan mempergunakan model Cooperative Learning tipe Course Riview Horay terjadi kenaikkanyang awalnya disiklus I rendah, kemudian meningkat hasilnya disiklus II.

Sesuai observasi yang dilaksanakan pada lembaranobservasi aspek guru serta siswa memperlihatkan bahwasannyaketerlaksanaan pengajaran belum secara maksimal tetapi sudah meningkat. Dapat dilihat dari hasil observasi pelaksanaan aspek guru disiklus I yang memperoleh 
persentase $81,25 \%$ kualifikasi baik (B) sehingga disiklus II menaik 92,5\% dengan kategori sangat baik (SB). Selanjutnya pelaksanaan observasi pada aspek siswa disiklus I memperoleh $81,25 \%$ dengan kriteria $B$, mengalami kenaikkan disiklus II yaitu memperoleh 92,5\% dengan kriteria SB. Jadi dapat disimpulkan dari yang sudah dijelaskan bahwa pelaksanaan pembelajaran tematik denganmodel $\mathrm{CRH}$ dapat meningkat mulai siklus I hingga disiklus II.

$$
\text { Hasil pembelajaran siswa }
$$
dengan menggunakan model $\mathrm{CRH}$ terjadi peningkatan disetiap siklus yang dilakukan. Disiklus I mendapatkan $67,18 \%$ dan terjadi peningkatan disiklus II yakni 92,4\%.

Sesuai hasilnyabisa diketahui bahwasanya hasil pembelajaran tematik yang mempergunakan model $\mathrm{CRH}$ terjadi kenaikkan mulai siklus I hingga disiklus II.

\section{DAFTAR PUSTAKA}

Arikunto, dkk. (2015) penelitian tindakan kelas. Jakarta: Bumi Aksara.

Hanifah, dkk. (2010). Konsep Strategi Pembelajaran. Bandung: Refika Aditama.

Iskandar. (2012). Penelitian tindakan kelas. Jakarta Selatan: GP Press Group.
Jihad, Asep \& Haris, Abdul. (2013). Evaluasi Pembelajaran. Yogyakarta: Multi Pressindo.

Kadir, Abd \& Asrohah, H. (2014). Pembelajaran Tematik. Jakarta:

PT RajaGrafindo Persada.

Kunandar. (2011). Guru Profesional Implementasi Kurikulum Tingkat Satuan Pendidikan (KTSP) dan sukse dalamSertifikasi Guru. Jakarta: Kencana.

Kurniasih, Imas \& Sani, Berlin. (2014).

Implementasi Kurikulum 2013: Konsep \& Penerapan. Surabaya: Kata Pena.

Lena, M. S, dkk. (2019). Metode Penelitian. Malang: CVIRDH.

Shoimin (2014) 68 Model Pembelajaran Inovatif sekali. Yogyakarta: ArRuzz Media

Prastowo, Andi. (2013). Pengembangan

Bahan Ajar Tematik. Jogjakarta: DIVA Press.

Sani, R. A. (2015). Pembelajaran Saintifik untuk Implementasi Kurikulum 2013. Jakarta: Bumi Aksara.

Sugiyono. (2017). Metode Penelitian Kuantitatif, Kualitatif, dan $R \& D$. Bandung: Alfabeta. 